Coolabah, $\mathrm{Nr}$ 28, 2020, ISSN 1988-5946, Observatori: Centre d'Estudis Australians $i$

Transnacionals / Observatory: Australian and Transnational Studies Centre,

Universitat de Barcelona

Digressions on Davis and the Natterjack Toad

Dennis Haskell

dennis.haskell@uwa.edu.au

Copyright $\odot 2020$ Dennis Haskell. This text may be archived and redistributed both in electronic form and in hard copy, provided that the author and journal are properly cited and no fee is charged, in accordance with our Creative Commons Licence.

\begin{abstract}
A series of humorous anecdotes about the author's friendship with Geoff Davis and a poem written in his honour
\end{abstract}

Keywords: Geoff Davis, sense of humour, friendship

This Geoff Davis issue of Coolabah is a fitting tribute to a wonderful, intelligent and dedicated scholar. Inevitably it is elegiac, and as such provokes in me an impulse to write about him directly rather than about his work; others can do that better than me. I would never want to disparage Geoff Davis's substantial contribution to Commonwealth and Postcolonial Studies but he was unusual amongst academic researchers. Never the distant scholar, he had distinctive personal qualities: humility; a great sense of humour; downto-earth unpretentiousness; endless curiosity; an open friendliness; a love of the arts, especially - apart from literature - of music; and joie de vivre. He had enormous love of learning and of life.

We first met when he visited the University of Western Australia but I already knew his name, and as an Australianist who sometimes ventured into Postcolonial Studies I knew some of his work. During a period of high theory which seemed to distance literature and even language itself from experience, Geoff Davis's writing firmly placed literature in the midst of people's lives and implicitly saw elements of common humanity, whether they lived in South India or South Africa. His work was writing, not "discourse".

Geoff's visit resulted in an agreement between the Arts Faculty at the University of Western Australia and RWTH-Aachen, partly because he knew Alexandra Ludewig, who came from Aachen and taught German Studies at UWA. This led to my coming to Aachen as a visiting scholar in 2000; I taught an Australian Literature course at RWTH to bright, interested students, a little surreptitiously since I was simultaneously supposed to be on a By-fellowship at Cambridge University. For this reason the semester-length course was compressed into six weeks; it seems totally in character for Geoff to be helping an 
Australian to subvert Cambridge's official rules. Six weeks seems a short time but it was memorable for my wife and me, partly because of the ongoing friendship we formed with Geoff and with Peter Marsden. Geoff and Ingrid had married not long before, and it was a very happy time for him. He showed us wedding photos, and sometime later offered words to the effect of "I don't know why she's interested in an old bloke like me!" It's a question Ingrid could readily answer but it showed his customary self-deprecation.

Amongst memories of that time is a rushed trip one evening to Köln (Cologne) for dinner and a concert by the Orchestra of the Age of Enlightenment, conducted by Simon Rattle. We drove to a station, then caught our train; I can't remember what station we drove to but the freeway was crowded, Professor Davis hadn't allowed enough time, and dressed in our best gear we had to run furiously for the train. Geoff bought the concert and train tickets and wouldn't take any money for them, the concert hall was rounded in beautiful timber, and the concert was superb. Looking back, all these details seem inevitable, since they fit so well with Geoff's indomitable character.

He also drove us to Antwerp one Sunday; as we crossed the German-Belgian border, its guard stations now crumbling and becoming overgrown with grass, Geoff commented, "It shows you how useless and unnecessary they were in the first place!" He had a spirited interest in politics and a lively distrust of authority. As we walked into Antwerp we passed a large window which held two slightly overweight, scantily clad ladies; Geoff, actually a touch embarrassed, remarked, "That's what you get in European cities these days". He had great a regard for human dignity. I still have a photo of Geoff scanning the map of Antwerp with my wife laughing at him, and he laughing at himself, as we wandered around the city, trying to find the car and lost! But he eventually found the way - Ingrid tells me that he was a Boy Scout. In some ways he always was.

I made a trip back to Aachen in 2012 and stayed with Geoff while Ingrid was away. I slept on a mattress put down in his stupendous study - books and papers everywhere, but Geoff had a scruffy control of them. Among other subjects, we talked about the Beatles; he had grown up near Liverpool and I was envious that he had seen them in their early, legendary days at The Cavern. He told me that the management didn't like the way couples stopped dancing and just stood and listened when the Beatles played - they were that good. He commented memorably that younger people knew the Beatles' music but, unlike our generation, they "didn't have it in the blood!" It was only at this time that I learnt he had been adopted; he'd had a happy childhood and, interestingly, held no inclination to look for his biological family.

When invited to contribute to Geoff's festschrift I felt the same impulse for personalisation I feel now. I wrote a poem rather than an article - which says as much about him as about me. The poem is reprinted here, in its comical, ridiculously rhyming couplets. It also says a lot about Geoff Davis that I knew he would be delighted by my making fun of him. Later, others told me that he loved the ending, about "the greatest empire, the empire of friends". (I hasten to mention that the Lawnmower Museum and the Natterjack Toad in his home town are real!) 
In 2014 I was invited to the EACLALS conference in Innsbruck, and had another chance to read the poem publicly in Geoff's presence. Although we lived many kilometres apart, it would be hard to think of a more generous, more genuine friend. I think he would appreciate that I'm writing this in a café in Kaohsiung, Taiwan - it seems appropriate for such an internationalist. Now that I have entered a senior age myself, with friends and contemporaries dying around me, I have this curious feeling that friendship never ends. Geoff's friendship has not ended for me, even if he is no longer on this earth, and I suspect that many contributors to Coolabah feel exactly the same way.

\section{A Tale of Two Cities}

(for Geoff Davis)

I wrote those words, gave a short shriek and cursed:

Some pommy bastard had pinched my title first!

But since it sets down just what I have to say

I think I'll use the damned thing anyway

For although many a pommy bastard may be miffed

It won't bother the subject of this festschrift,

Who first faced life in sandy Southport: Southport, It's in the north of course, a sort

Of directional confusion, a sandbank of delusion

To you and me, fed by the fervour of the Irish Sea,

A town over which sand, like boredom, flowed,

Home of the Lawnmower Museum and Natterjack Toad,

But so near Liverpool, with people who thought fit

That the city turn out another mock-Scouse git

Where sea and sky unite in a grey more ugly than

The grit guffing the soul of every Liverpudlian,

But not our Geoff's. Every tide must have its turn

And in his youth every youthful eye would yearn

To be where sea shanty and skiffle riffed on dixies

Brought in the frank and frisky, frenzied sixties

When the hip got high and sexy, and their parents apoplexy

To the pulse of Cilla Black, Merseybeats, the Undertakers

- The Cavern would have ‘em, plus Gerry's odd Pacemakers -

And every young mouth could shout the lingo

Of John and George and Paul and Ringo.

Even now many think that's what Liverpool gave us

But what it really gave us, God save us, was Davis!

With rocking sounds below and endless drizzle above

He might be the walrus but money can't buy me love;

By these shores our hero might long have lingered 
But it's not every city has an Ingrid.

So he danced into Deutschland, almost by chance

- I think he mistook it for the south of France;

Despite his earnest search for eminent champagne

He washed into the beery city of Charlemagne

Where for centuries people had argued like hell

Whether they were in farkin' Aachen or Aix-la-Chapelle.

Great Karl came here for a spa, and refused the warpath,

Geoff was keener on a bar, but I say on his behalf

Even an Englishman eventually needs a bath!

Perhaps he thought he'd enjoy an inky Saturnalia

At the Technische Hochschule of Rheinish Westphalia

To which ardent students came, to learn, to love, to laugh;

Geoff just sort of wandered in, and joined the staff

And from a pile of papers and mess unceremonial

He wrote and spoke and spoke and wrote of literature postcolonial.

Nothing dodged his radar: the praise poem, the novel petit bourgeois,

A brouhaha in Zanzibar or the cha cha cha in Chandigargh:

That scholarship and editorship indefatigable

Educed a worldwide German English wisdom enigmatical.

"Geoffrey" - means God's peace, but so does nigh on every name,

Yet in your chaos and your zest there's something few can claim:

A generosity and lack of ego in everything you do

So we see you centred in an empire Charlemagne never knew;

For the absurd jibes above, our each word to you extends

The heart of the greatest empire, the empire of friends.

Bionote: Dennis Haskell has published 8 collections of poetry, most recently Ahead of Us (Fremantle Press, 2016) and What Are You Doing Here? (University of The Philippines Press, 2015) plus 14 volumes of literary scholarship and criticism. He is the recipient of the Western Australia Premier's Prize for Poetry, the A A Phillips Prize for a distinguished contribution to Australian literature, and of an Honorary Doctorate of Letters from The University of Western Australia. In 2015 he became a Member of the Order of Australia for "services to literature, particularly poetry, to education and to intercultural understanding". His website is dennishaskell.com.au 